\title{
The Social Structure in the GAP Region and its Evolution
}

\section{Selahattin Erhan}

To cite this article: Selahattin Erhan (1997) The Social Structure in the GAP Region and its Evolution, International Journal of Water Resources Development, 13:4, 505-522, DOI: 10.1080/07900629749593

To link to this article: http://dx.doi.org/10.1080/07900629749593

曲 Published online: 21 Jul 2010.

Submit your article to this journal $\pi$

Џll Article views: 60

Q View related articles $\square$

Citing articles: 4 View citing articles $\square$ 


\title{
The Social Structure in the GAP Region and its Evolution
}

\author{
SELAHATTIN ERHAN
}

Department of International Relations, University of Bilkent, 06533 Bilkent, Ankara, Turkey

\begin{abstract}
GAP is an integrated multisectoral development project implemented in south-east Turkey, which makes up $9.7 \%$ of the country. With its technical, economic and social dimensions, it is considered in western circles as one of the three to nine wonders of the modern world. As distinct from earlier projects implemented in Turkey (e.g. the Çukurova Plain project) and elsewhere in the world, the main objective of GAP is to improve the living conditions of the people not merely by developing the material infrastructure but by taking the people as the core factor in every component of the project. The sustainability of such projects, it is well realized, depends on the human dimension, and not on success in the achievement of the material goals alone. Within this framework, several sociological research studies were conducted in the region to determine the appropriate approach in making the people a vital component of GAP and in bringing them to participate in the project voluntarily. This article first gives a historical account of nomadic, i.e., 'tribal' (or ashiret) aspects of Anatolian history, without which neither the past nor the present of Turkey can be adequately understood. It then proceeds to summarize the findings, regarding the 'tribal' structure in the region, of the several research studies carried out in the region between 1992 and 1994.
\end{abstract}

\section{Introduction: The Scope}

Since early times, Anatolia, the main body of the Republic of Turkey, has been a place of cultivators. According to geographers (e.g. de Planhol, 1959), almost all of its land is suitable for agriculture. Despite that, from the 10th century onwards, nomadism became the predominant life style in the majority of the peninsula. Therefore, I maintain, the history and hence the present structure of Turkey, and more so of south-east Anatolia, cannot be fully comprehended unless its nomadic past is appropriately taken into consideration in any analysis regarding the social formation and culture of the country.

While the population of Anatolia was composed of cultivators until the 10th century, this situation has changed thenceforth. Waves of people came in mainly from the east, and these newcomers had a variety of social groups and strata, from fully sedentary urbanites to full-time nomads (Sümer, 1960). A significant fact is that the main bulk of the incomers were predominantly nomads, whose survival depended on their animals, and life on their mobility and military capability. To recapitulate, one of the major factors promoting nomadic survival in the Anatolian peninsula, and hence some form of 'tribal' or ashiret organiza- 
tion, has been massive westward migrations, mainly from Asia. Thus began the predominance of nomadic existence in Anatolia around the 10th century. The first migration after the establishment of nomadism in Anatolia, which brought with it a 'tribal' form of organization to the peninsula to an extent which has never been experienced before was the 13th-century Tartar/Mogul influx. The second major influx of nomadic peoples came about the time that the Osmanl Beylik (principality or emirate) was expanding at the expense of the Turkmen Beyliks in Anatolia. Later, with the emergence of the Safevi political influence in Iran in the 14th century, migrations turned back towards the east (Demirtaş, 1949, p. 38; Sümer, 1980, p. 156), and remained so until the arrival of Tamerlane (or Timur the lame) at the turn of the 15th century, which brought another major wave of nomadic immigrants to Anatolia. This mass move of the (tribally organized) nomadic people under Tamerlane once more successfully revived nomadism, especially in the eastern half of Anatolia.

In a sense, the founding of the Iranian Safevi state in the early 16th century, whose roots are to be found in the sufi sect of the 14th century, was parallel to that of the Osmanlı in the west. However, while the former remained much more loyal to the Turkmen who had founded it, and who had borne the main burden of its establishment (Sümer, 1976), the latter rather swiftly changed its policy towards nomads once it was strong enough to do so.

\section{Ottoman Policies of Containment and Settlement}

The subordination of Anatolian nomadism greatly accelerated in the 17 th century. ${ }^{2}$ From the view point of the Empire, the most critical factor in the 17 th century was its inability to maintain its borders as a result of several defeats in the west. The Empire had already undergone a serious decline in its agricultural population at the end of the Great Escape in the first half of the century. It came face to face with a drastic fall in production and hence suffered famine in most regions of Anatolia (Akdağ, 1975, p. 61ff.). Furthermore, "the Celali rebellions of the later sixteenth century ... made it increasingly difficult to guarantee the safety of merchants and their goods" (Faroqhi, 1982, p. 523). The result was a one-third decline in tax revenue in many regions. To solve this double-edged problem (i.e. military and financial) the central government applied military force. On the one hand, it attempted to keep rural people where they were and to send those who had emigrated to the cities back to the countryside. On the other hand, it tried to extract the same total amount of tax from those who did not leave their villages, all the while trying to impose additional taxes upon them to finance the costly military expeditions. ${ }^{3}$ These practices only worsened conditions in the countryside. The administration eventually relinquished this policy, and tried to resettle the vast areas left idle either by sending the rural population back to their homes or through attempts to repopulate them with nomads and immigrants from the lost provinces.

A fresh effort at reforming the military began at about the same time. The devshirme system of the yeniçeris was now far from efficient. The yeniçeris were undisciplined and weak. Thus began the recruitment of the yörüks in the Balkans. However, a great majority of the yörüks in the Balkans were long settled (i.e. oturak) and did not view active military service as an enticing prospect. To bring the people to the calling, the government granted them the honorary title: Evlâd-ı Fâtihân, i.e. Sons of the Conquerors. Second, it exempted them from all 
the taxes they had previously been forced to pay as reaya (Gökbilgin, 1957, pp. 255-256). The establishment of the Evlâd-ı Fâtihân troops in 1691 posed new problems for the state. Though the Balkan yörüks were not enthusiastic about this project and were pressed into service only by these ideological and economic measures, many people from the Anatolian countryside tried to join these troops by claiming that they too were yörüks. Others took a more negative attitude and rebelled, or seized this occasion as an opportunity for resisting any taxation whatsoever (Çetintürk, 1943, p. 116).

While the Government was organizing the long-settled nomads as EvlâdFâtihân in the Balkans, it initiated a comprehensive settlement project in eastern parts of Anatolia and Syria in 1691. The south-eastern extremes of Anatolia were under continuous assault by the Bedouins (or the Badawi,i.e. the desert nomads) from the south (Orhonlu, 1987, pp.45-46). Here the frontiers were reinforced against the Safevî and the social disorder caused on the arable lands of Anatolia by the Bedouins. The areas chosen for (re)settlement were Raqqa, Hama, Humus and Aleppo in Syria, and the area covering mainly the west between the Adana and Tokat provinces in Anatolia (ibid., 1987, pp. 32, 55-87; see also Bates, 1971a). Whereas the main concern in establishing the Evlâd-ı Fâtihân was military, the settlement of Anatolia and Syria involved social and economic dimensions as well as establishing order on the eastern and south-eastern soil (Orhonlu, 1987, pp.37-45, 56). Furthermore, those nomads settled in Anatolia and Syria were considered among the causes of the socioeconomic instability of Anatolia by the administration (Uluçay, 1955, pp. 80-85).

Settlement of nomadic ashirets in earlier centuries in the Balkans and elsewhere was part of the colonization of newly conquered lands. The new project indicated an "introversion of settlement policy" (Orhonlu, 1987, p. 96) in that it attempted to repopulate the heart of the Empire. In other words, the Osmanl were now trying to maintain control of the mainland where their power rested for so many centuries. Although the choice of both Anatolia and Syria involved similar concerns, an additional military role was assigned to the settlers along trade routes and/or borders, who thus received some extra rights. While the former settlers in the Balkans and elsewhere were regarded simply as reaya, i.e. commoners, in socioeconomic term ${ }^{4}$ and were taxed accordingly (ibid., 1987, p. $71 \mathrm{ff}$.), the latter were exempted from several taxes (ibid., 1987, p. 47), thereby becoming the askerî, i.e. military. Those assigned as militia to guard the derbents (mountain passes) were also allowed to engage in pastoral production as long as they did not change locations seasonally. In order to guard the trade routes and to stand as permanent frontier forces, they had to stay on the spot all year round $(1987$, p. 47). They could pursue their 'traditional mode of life' only by sending their herds to the highlands with their shepherds in summer (ibid., 1987, p. 51). Quite realistically, the government did not expect to prevent communal seasonal movements by law alone, and secured them by force (ibid., 1987, p. 51; see also Bates, 1971b).

The common practice of the Osmanll was to settle nomadic 'tribes' in fragments away from each other in order to prevent any rapid recovery of their previous power or unsupervised movement (Orhonlu, 1987, p. 56). This time, however, they were settled along the borders or trade routes in large groups so as to facilitate the performance of their military duty, to protect those borders and trade routes (Aswad, 1971). Since such ashiret settlements might well start causing trouble themselves, the government took several measures to preserve the stability of the settlements and their loyalty. The chiefs and other notables, 
i.e. beys and kethüdas, who had high standing both within their communities and in the eyes of the state, were given the largest and best lands. The chiefs' willingness to settle $\mathrm{w}$ as instrumental in bringing them considerable land titles as well (Orhonlu, 1987, p. 57).

The 1691-96 settlement project was a multidimensional one. To the Osmanl, rural settlement was the only way to counter the problems of decreasing rural population, crop damage caused by irregular nomadism, and external threat. Banditry and raids on dwelling areas were largely ascribed to the nomads-usually, quite rightly so (see Bayrak, 1984). In many cases, the disruptive groups were reported to have come from eastern Anatolia and Syria, where they had earlier been forced to settle. ${ }^{6}$

Large numbers of Crimean and Caucasian agricultural immigrants were settled next to the nomadic ashirets, if not directly on the pastures used by them. Thus, in these border areas and trade-route passages vacated by the people during the upheavals leading to the Great Escape, not only was security expected to be maintained but also a very critical balance was intended between the experienced cultivators and nomadic settlers. The incoming people had recently lost their ancestral lands, and were determined not to experience the same fate again. They represented a strong and intransigent foe for the nomads, who were not pleased at having been reduced to immobility. What is more, the two could successfully stand together against the advance of a common enemy, such as the Shammar and Aneze Bedouins of Arabia (Orhonlu, 1987, pp. 45-46). The presence of nomads as 'tribal' settlers was also seen as a factor that would control local 'feudalistic tendencies', 7 which had already emerged in the 17 th century (Uluçay, 1955, pp. 71-74).

It was not easy to prevent nomads from abandoning their assigned plots (Orhonlu, 1987, pp. 81ff, 88ff.). The land and its natural resources were often claimed by nomads to be insufficient. Furthermore, as settlers, they were subject to recurrent attacks of stronger or Bedouin groups from the south (ibid., 1987, p. 90). Finally, new taxes were imposed on them and were regularly extracted after they became 'sedentary,' i.e. immobile. So, many of them left their settlement zones to avoid strict political control and taxation, and fled into areas where they could more readily cope with the pressures imposed by the governors.

This time their flight was not exclusively toward the west or north. A principal alternative was the east. Iran had been a preferred destination for many nomads since the 16th century, and it continued to be so during the 17 th and 18 th centuries (Demirtaş, 1949, p. 38; Sümer, 1980, pp.303-304). The extent of the eastward migration and hence its impact on the Osmanlı in Anatolia was quite substantial. For example, on one occasion in the 18th century, 50000 nomads left their lands around the Taurus mountains, and went to Iran (Yalman, 1977, I, pp. 49, 102; Sümer, 1980, pp. 303-304).

As a result, initial attempts at repopulating the Anatolian countryside and increasing agricultural productivity largely failed, despite some temporary successes (Orhonlu, 1987). Nor were the issues of safer trade, transportation and the like completely solved.

\section{Eighteenth Century: Nomadic Ashirets as Guards, etc.}

Consequent upon this failure, a more comprehensive approach was adopted by the Osmanli in the 18th century to re-establish overland communications, among 
other concerns. "This policy involved the construction and repair of fortified kervansarays and the reorganization of the corps of passguards (derbendci)" (Faroqhi, 1982, p. 523).

This time, many of the reasons people gave for fleeing or resisting settlement on assigned plots began to be given more serious consideration (Halaçoğlu, 1988). The declared aim was still to populate and cultivate the devastated countryside, by bringing security and stability back to Anatolia. However, the Osmanlı were Osmanlı and acted like Osmanlı more often than not. Thus, special forces like Fırka-ı Islâhiye were sent against resisting nomads, and there were many armed clashes. Due to some talented, able governors, some successes were achieved at least temporarily in certain regions in Anatolia (ibid.) and Syria (Lew is, 1987).

In the meantime, reformation of military organization continued at full speed. One of these attempts was the establishment of the Nizâm-ı Cedîd (literally, the New Order) army in 1793. The resistance of the long corrupted yeniçeris was so fierce and strong that the attempt could not go further than trying to maintain the new regiments as special guards, downplaying their role and keeping both their numbers and public appearances very low.

In addition to the establishment of a new central army, the state also tried to reinforce and strengthen the old frontiers, as well as establish new ones. "The final steps ... to extend central control into the provinces involved a major reorganization of the army" in 1841, which was for "the first time divided into provincial commands" in an attempt to counter and terminate the local "governors' control of the military forces within their domains" (Shaw \& Shaw, 1978 , p. 85). In addition to these forces, the "irregular tribesmen, generally called bashıbozuks," assisted the provincial divisions "with some 65000 warriors" (ibid., p. 86).

The Balkan troops of ex-nomads founded in 1691, Evlâd-ı Fâtihân, were reorganized in 1832 (with the same exemptions and privileges), and were deployed not only in the west but also in Georgia, for instance (Gökbilgin, 1957, p. 256). Owing to the desperate need for their services, the privileged status of the Evlâd-ı Fâtihân continued until 1850 when the Tanzimat, i.e. Reformation, government of 1839 announced military service to be a duty of all citizens (ibid., p. 256). A new Land Act followed this law in 1858, which:

... in combination with following numerous decrees of execution, led to a stabilization of law and order in the country, especially regarding the most important security of property. Property of land-till then only possible as mîrî, a form of copyhold-could now be changed into a legal title of ownership. (Hütteroth, 1973, p. 23)

While this law stimulated the expansion of agricultural production via the legalization of the cultivation of additional lands such as pastures, which probably had already begun, it did the opposite to nomadism. In addition to the decrease of pastures available for grazing, many dwelling-places (left idle by villagers), presumably used by nomads on a seasonal basis, were now being revived by the settlement of "hundreds of thousands of Muslims ... emigrated from the Crimea, Caucasus, and the Balkans" following their loss (ibid., p. 23).

These developments, combined with the continuing attempts of the government to control them as sedentaries, ${ }^{9}$ put the nomadic confederations in a very constrained situation. As a result, some volunteered for settlement (see Yalman, 
1977, I; pp. 215, 216). Many refused to oblige and moved further east while others were already continuing to enjoy a relative 'freedom' in quite large confederations. Others joined nomadic groups after leaving the lands on which they were settled by official decrees (ibid., 1977, I, p. 251). Some ashirets resorted to banditry because of the difficulties of adjusting to a settled life (see Boran, 1945, pp. 31-32).

However, the Osmanlı do not seem to have followed a policy of settling all nomads. As Bates sees it, it was "a project which arose from the government's desire to bring politically threatening tribes under control" (1973a, p. 225). ${ }^{10}$ To achieve this goal, it seemed the best and easiest way for the state to grant land titles to the chiefly figures of every tribal group. This thereby initiated "the rise of large private estates" in south-east Anatolia (Aswad, 1971, p. 21; cf. Beşikçi, $1969 \mathrm{~b}$ ) where "many of their descendants are found among the largest landlords of the region today" (Bates, 1973a, p. 225).

As noted above, local notables were already emerging throughout Anatolia as 'feudalistic' derebeys, with almost-absolute powers over the reaya. The policy of giving arable lands to notables as private holdings, in addition to the collective or communal lands granted to the settling confederations, in time led to an enlargement of the estates and, hence, the expansion of the power of the notables at the expense of the masses (cf. Sencer, 1974). Notables acquired lands through a variety of means, from illegal coercion and appropriation to legal transfer. Also partly because of nomads' inability and unwillingness to stay and engage in cultivation on the assigned plots, in the end all the land turned into the private property of these ashiret notables, who now became local (land)lords while the ordinary nomads gradually became dispossessed tenants. After getting rid of the large and more threatening confederations, the government allowed the others who "offered no threat to the political stability of the region", to continue their usual way of life (Bates, 1973b, p. 34).

\section{Revival of Nomadism in Eastern Anatolia: The Hamidiye Cavalries}

In the last quarter of the 19th century, further events occurred that accelerated the revival of nomadism (and, thereby, the ashiret structure) in eastern Anatolia. In direct cooperation with the Russians, who were continuing their advances through Caucasia in the north-east (which is on a major trade route between Caucasus, Iran and Anatolia), the Osmanlı Armenians initiated guerilla activity behind the army lines so as to help the Russians defeat the Osmanll. The British were another concern. The British had already 'rented' the province of Cyprus unilaterally in 1878 (Kodaman, 1987, p. 25), and annexed Egypt in 1882 (ibid., p. 68), all under the pretext of preventing the Russians from doing so. Hence, they were rightly suspected of having further ambitions concerning Osmanl lands, extending from north-east Anatolia to the Arabian peninsula.

These developments led the central government to adopt a rather traditional strategy. In 1891, the state organized 36 regiments (Firat, 1983, p. 123), from among the ashiret (i.e. nomadic and semi-nomadic) warriors of eastern Anatolia (Kodaman, 1987, pp. 44, 49). ${ }^{11}$ Two important criteria for selection were the size and power of the groups. Large and strong confederations that could rise against the state in a conflict were not the first choice. Adherence to sunnî Islam was preferred, though not steadfastly followed (see Kodaman, 1987, p. 37). The purposes were varied, three of which were: "to help the army suppress 
terrorism in the east" (Shaw \& Shaw, 1978, p. 203), "to counter the Russian Cossack forces in the Crimea, and also to control the tribes themselves by 'placing' nomadic areas adjacent to the Russian border" (ibid., p. 246; cf. Beşikçi, 1969a, p. 79).

These cavalry were named after the Sultan Abdul Hamid as the Hamidiye [Hafif Süvari] Alaylar, the Hamidiye [Light Cavalry] Regiments ${ }^{12}$ and initially consisted of some 50000 men who were "paid on active duty" and their families "exempted from all taxes except the tithe [öşür] and animals tax" (Shaw \& Shaw, 1978; p. 206). Their arms were provided by the state and although they "were supposed to be provided only when they were engaged in combat ... in fact most of them managed to keep" them even after the war (ibid., p. 206). These regiments were not totally free from government control. Although they were actually "commanded by the tribal chiefs ... regular army officers also went along to train the men and make sure that the overall commands were carried out" (ibid., p. 206).

These regiments provided the means for nomads to foster their privileged position in the region and, consequently, the "Hamidiye tribal force grew fairly rapidly, to 40 regiments in 1892, 56 in 1893, and 63 in 1899" (Shaw \& Shaw, 1978, p. 206). One reason was the regulation enacted for their recruitment, which stated that the people had two choices: either to be recruited for regular army service; or to become irregulars under the Hamidiye troops (Kodaman, 1987, p. 37). This expansion was realized also through force exercised by the Hamidiye chiefs (see Firat, 1983, pp. 125-126) as well as through the independent initiative of other chiefs, who had initially been hesitant or even unwilling to be recruited.

The appeal of these regiments can also be located in their organization and its effects (Firat, 1983, pp. 124-126). In fact, this seems to be the main reason why the chiefs who at first hesitated to join the regiments and were thus left out of the Hamidiye organization later became eager supporters of it. They realized that the early founders of the regiments soon became stronger and more respected than they could have ever dreamed had they not joined these forces. Many chiefs immediately became commanders of a combination of several small kabiles or ashirets in addition to their own kabile or ashirets, thereby becoming leading figures in the region.

One consequence of the establishment of the Hamidiye regiments $\mathrm{w}$ as the division of the people into two antagonistic groups. Those who were serving in these regiments became "the Hamidiye" vis-à-vis the others. For more than two decades, the previous names and titles of the people involved in the Hamidiye organization were subsumed under the more comprehensive and legally auth-

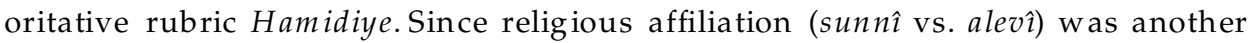
concern of the Osmanli in appointing the increasingly willing candidate warriors as Hamidiye, sectarian antagonism ${ }^{13}$ resurfaced and rose to an unforeseen magnitude between the two groups, adding greatly the strains felt between them later (see Firat, 1983, p. 158ff.). ${ }^{14}$

On the death of Sultan Hamid in 1909, the Hamidiye chiefs found themselves in a dangerous vacuum. The new government did not seem to share the policy of the deceased Sultan. As opposed to the sunn $\hat{\imath}$-oriented Islamicist policy of Abdül Hamid, the new government adopted an Ottomanist view to (re)unite the badly divided population of the Empire, Christians, Jews and Muslims alike (Çavdar, 1984). This policy found immediate support among the non-Hamidiye alevî communities in eastern Anatolia, who had suffered most severely from the 
divisive consequences of the earlier policy (Frrat, 1983, p. 141ff.). Partly because of being left powerless by the death of the Sultan, whom they considered a father (ibid., p. 125), and partly because of the threat posed by the alliance between the new government and the alevî ashirets, some of the commanderchiefs rebelled immediately after the announcement of the era of the Second Constitution (Meşrûtiyet) in 1908, but were subsequently defeated by regular troops. ${ }^{15}$ Only after these defeats and under strict governmental control did these irregular nomadic regiments give up fighting the new regime.

The Meşrûtiyet government did not dissolve the regiments but chose to control them more directly. Now, each regiment had a regular major as its second-incommand (Frrat, 1983, pp. 141-142). Again, according to the law, raiding and tax-gathering were no longer permitted (ibid., p. 142). Despite these restrictions, the chiefs did not lose their power and authority either among the troops or among the sedentaries of the region (ibid., pp.141-142). They still proved helpful to the government in war. In 1912, they were put on alert because of the Balkan conflict in the west. The continuing threat of the Russian Empire forced the government to maintain and train Hamidiye regiments in the east. At the beginning of the First World War in 1914, the Hamidiyes were sent against the Russians. Though they fought to the best of their abilities, they were defeated. Most of them fled back into the mountains where they began to engage in banditry and raiding.

Those who stayed at the front were reorganized and gathered into two divisions, which survived until about 1920 (Firat, 1983, pp. 143-444). They adamantly resisted dissolution, and remnants of them (even after their official disbanding) caused the Osmanl government many headaches. Aside from trying to exact illegal taxes from villagers and non-Hamidiye ashirets, they engaged in fierce fights with one another. Besides such inter-ashiret warfare, the ex-commanders turned into local 'despots' known as the derebeys of absolute power, with hundreds of armed men at their command. These events created widespread unrest in the region. But the Osmanlı found themselves on the losing side during the closing stages of the First World War, and were in no position to put a stop to such illegal activities anywhere in the country. İstanbul was under allied invasion. In the east, nomads and the ashiret system were once again on the rise, and in the midst of the chaos created by the power gap at the centre from losing the war, raids and banditry became taken for granted as daily events (ibid., pp. 155-156).

\section{The Present Conditions of Nomadism in Turkey}

Under the new regime, the privileged nomadic groups and their leaders had to relinquish their legal/official titles, administrative and military rights and duties, such as collecting taxes (Frrat, 1983, p. 141ff.). A second development was the closure of the eastern and south-eastern borders in the late 1920s and the 1930s, which curbed the migratory orbit of nomads drastically, and reduced the area that they could exploit. Furthermore, some of the disbanded ex-Hamidiye ashirets were left outside Turkey. Later on, the enactment of the Village Act in 1924 turned the power relations between nomads and villagers completely upside down. This Act was designed to protect the interests of villagers against intruders such as nomads and converted the traditional grazing plots, highlands and pastures that nomads had been using into the common property of (the 
nearest) villages (Tütengil, 1969, p. 128). Depending on their own productive orientation, the villagers chose either to exploit the pastures themselves, or to rent them to nomads (who were now stripped of this basic economic means) at high rates. Since, however, many of these villagers were ex-nomads settled earlier, they too retained an ashiret structure similar to that of the nomads, if not exactly the same. More precisely, the conflict was now also one among ashirets.

Consequent upon the process sketched above, contemporary nomadism is strictly dominated by the sedentary way of life into which it becomes more incorporated every day. In contrast with the political power they held in the past, which lasted until the 1930s, pastoral nomadic ashirets today are subordinate to the agricultural population. The present regime is organized on the basis of a settled way of life. Hence, nomads, who are a priori considered as "the people of no land", do not stand a chance against villagers when conflicts occur, unless they are either backed or represented by an able person in the region. The official de-recognition of (nomadic) ashirets as legal communities by the foundation of the Republic in 1923 undermined the leadership and made the allegiance of their members to certain ashiret leaders contrary to the ideology of central government. In most disputes between villagers and nomads, therefore, the law, and hence security forces, are on the side of the villagers unless, to repeat, they are aligned with local power foci.

As a result of the developments and policies described earlier, eastern and south-eastern Anatolia became a refuge for nomads. A simple observation in the Republic of Turkey reveals that there is a "clearcut contrast" (de Planhol, 1959, p. 529) between western Anatolia and eastern Anatolia in terms of nomadic, i.e. ashiret, survival. Until about two decades ago or so, nomadism was quite vestigial in the west, and practised mainly between the coastal plains and the plateaux near Kayseri (in central Anatolia) by several fragmented groupings of the Aydinli group (Eberhard, 1967, p. 282) and by the remnants of Bozoloğ, i.e. Boz-Ulus (Yalman, 1977, Vol. II). In eastern Anatolia, on the other hand, nomadism experienced "a much more vigorous survival" (de Planhol, 1959, p. 529) until quite recently. If one reason why nomadic survival was much more vigorous in the east is the suitable climate and geography, another factor which resulted in the prevalence of nomadism in the east has been the differential rate of agricultural mechanization and commercialization (Erhan, 1992, p. 88) in Turkey. Furthermore, as a result of the developments and policies described earlier, eastern and south-eastern soil had become a refuge for nomadic ashirets until about a couple of decades ago. Studies show that even in the 1980s there were some pastoral nomadic ashirets in eastern Anatolia such as the Şavaklı of the Elazığ-Tunceli-Erzincan range which had as many as 15000 members (Aydın, 1980 , p. 143; Kutlu, 1987, p. 53). One should add the Beritanle ashiret to this list, the number of whose members, regardless of their active involvement in nomadic pastoral practices, easily equalled the Şavakl, if not exceeded them (Erhan, 1992).

Indeed, one of the most distinguishing social characteristics of the population in eastern Anatolia is its as yet undetached ashiret affiliations which at times of inter-group conflict, such as feuds, prove themselves to be a major basis of solidarity and cooperation (Hakk1, 1932; Sencer, 1992-93, pp. 609, 614-615). ${ }^{16}$ In other words, the prevailing ideology which ultimately governs social relations in most parts of the region is that of ashiret organization, i.e. genealogical kinship relations; social belongingness; and the notion of "community", as "a sense of 
belonging together" Brow (1990, p. 1). ${ }^{17}$ The same is true for the (sedentary) rural population, as well as many people of the towns and small cities, which either have been practising a semi-settled way of life or have become sedentary cultivators during the last two hundred years or so, mainly through the government operations described above (see also Sencer, 1992-93, p. 614). At this point, it is worth mentioning, in the words of Sencer (1992-93, p. 611) that "It is a very rare situation to find an ashiret which is completely nomadic or settled".

Largely as a result of this structure, eastern (and, by the same token, southeastern) Anatolia did not seriously take part in the process of mechanization until the 1960s. Most people in eastern Anatolia were landless and organized in ashirets, and the landlords would appear to have had very little to gain from using modern machinery. ${ }^{18}$ On the one hand, machines would replace large numbers of rural people, landless and landed alike, who for the most part belonged to the same ashiret as their landlords. Thus, the calculation involved in adopting (or, for that matter, refusing the use of) new machinery was not simply an economic one. The machines would perhaps bring about an increase in the yield. But, once the machines were introduced, the ashiret leaders, who had become landlords in the process of settlement, would lose their 'dependants', i.e. the social base of their political power (Erhan, 1992, see also Sencer 1992-93, p. $616 \mathrm{ff}$.$) . In effect, then, ashiret forces were threatened. The introduction of$ machinery would have encouraged the break-up of fundamental social relations in favour of capitalist penetration. Nevertheless, quite aware of their eventual fate, the local leaders (such as the sheikhs and ashiret chiefs) not only-and forever-did resist mechanization but also have renewed themselves quite successfully and adapted to modern conditions. As an example, they began to get actively involved in national party politics so as to maintain their position and roles as local leaders and mediators (see Erhan, 1992, 1993; ODTÜ, 1993, p. 19; Sencer, 1992-93, pp. 614-615).

\section{GAP and Its Prospects}

At present, however, even the nomads of this region are continuously losing ground at an ever increasing speed. At this point, Sencer notes (1992-93, p. 612) that the ashiret population "whose estimated number was approximately 70000 100000 at the beginning of the 1970s" is in a process of settlement due to the shortage of summer and winter quarters and the like. The conditions once relatively suitable for nomads in eastern and south-eastern Anatolia are now subject to drastic changes. The most comprehensive and most current of these changes is GAP, namely Güneydoğu Anadolu Projesi, or the Southeast Anatolian Project. GAP is an integrated multisectoral development project covering the nine provinces (Adiyaman, Batman, Diyarbakır, Gaziantep, Kilis, Mardin, Siirt, Şanlıurfa, Şırnak) of the south-eastern corner of Turkey. The area in question makes up $9.7 \%$ of the country, and with its technical, economic and social dimensions, the project is considered by several western circles as one of the three to nine wonders of the modern world. This development project includes 13 sub-projects, the totality of which aims at a hydraulic complex able to irrigate $1800000 \mathrm{ha}$, so as to increase agricultural production up to 50-60 times (Balaban, 1986, p. 5). This figure is 300000 ha more than the total irrigated land in the whole of Turkey at present.

Balaban notes $(1986$, p. 3) that the preliminary steps of what is now called 
GAP were taken in 1936. However, feasibility studies proceeded only during the 1960s and were finished by 1970. With regard to its magnitude, the entire system was projected to be completed within a span of 30 years. At 1986 rates, it required a total of TL7 trillion, a sum which is equal to the same year's national budget. Initially, GAP was planned to be finished by the year 1990. Several reasons, including the so-called "Gulf Crisis" next door, precluded the completion of the project on time. Opening of the Atatürk dam, the biggest dam of all within the GAP system, took place on 1 December 1993. As of April 1996, the sub-systems of this vast integrated project completed so far could provide a total of 68000 ha of irrigation. The energy production of the two dams, Karakaya and A tatürk, amounts to $102630071000 \mathrm{kWh}$ for the same year. By the end of 1996, the total land irrigated reached $1693027 \mathrm{ha}$, which is equal to $19 \%$ of the total economically irrigable land in Turkey.

Despite the ensuing delay in the completion of GAP's physical investments, the picture looks quite dark for the nomadic-and, to a lesser degree, the semi-nomadic-ashirets of the region, whose culture and mode of organization have predominated there for many centuries. There are very few alternatives left for them, if they could be called 'alternative' at all. The most plausible one is to settle down and cease to be nomadic, thereby practising some combination of cultivation and sedentary animal breeding, inevitably at a much lower capacity.

Many nomadic groups have actually been seeking government aid to settle since the 1930s. The underlying idiom of state policy has been, as it still is, to convert nomads into cultivating villagers, if not also urban dwellers, and to make them productive as soon as possible after they settle (APD, 1971), rather than causing them to suffer the consequences of a prolonged transition. Thus, the usual practice of governments before 1970, under Law No. 2510 which provides the basic stipulations, was to provide every possible assistance to those seeking rural settlement, including land, fields, housing, agricultural equipment and the necessary infrastructure such as sheds, stables and roads (Gülöksüz, 1985, p. 307). The principal conditions of eligibility were simple and very strictly followed. They were, as they still are, to own no landed property anywhere in Turkey, and to be married at the time of the official settlement survey.

Since the 1970s, however, these benefits are provided only as loans with easy credit terms (as low as $2.5 \%$ interest), payable in instalments over five to 20 years. According to Law No.1306, as amended in 1970, "the property is not granted for free to the settlers, but rather they become indebted to the state for the disbursed expenses" (Gülöksüz, 1985, p. 307). Perhaps because the settlement of nomads has not been a primary concern of government in modern Turkey, in practice, a group that requests settlement usually finds a place and then notifies government agencies. If the piece of land is public property, then its current value is calculated by experts, based on an assessment of the quality of its cultivable land, etc., and is transferred to the group after the roads and houses have been built by the state. If the site belongs to private persons, then the government purchases it from its owner, to turn it over to the group when the necessary housing, roads, drinking water, stores and the like have been provided. At the time of settlement, the state also provides some initial capital, based on agreement with the group. This may be either seed grain/wheat or animals.

Nevertheless, what is true for 'nomadism' is not the same for 'ashirets', i.e. tribes and/or tribalism. An overwhelming majority of sedentary rural popu- 
lation in the region is organized as ashirets, thanks to the centuries-long domination of nomadism and the three-century history of governmental or voluntary settlement practices.

\section{Sociological Studies in GAP}

Aware of these and other issues concerning the population of the region, whose lives have already begun to change or are subject to be altered drastically soon, a major concern of the GAP project is to take into consideration the living conditions of the people in the face of the expected and/or projected changes deriving from the physical and the ensuing economic changes enacted in the region. In other words, as distinct from the earlier projects implemented in Turkey (e.g. the Çukurova Plain project) and elsewhere in the world, the main objective of GAP is not merely to develop the infrastructual facilities and/or to invest in material projects. The sustainability of such projects, it is well realized, depends not on success in the achievement of the material goals alone. Rather, it depends on taking the human element as the core factor in every single component of the project, successfully and appropriately. It is, so to speak, the human dimension which brings either the failure or success of any development project.

Between 1992 and 1994, four major researches were conducted in and on south-eastern Anatolia, through the initiative and sponsorship of the GAP-BKI (Southeastern Anatolia Project-Regional Development Administration). These include 'Survey on the Trends of Social Change in GAP Region' planned, designed and conducted by the Chamber of Agricultural Engineers under the supervision of Dr Muzaffer Sencer (1992-93); 'Women's Status in the GAP Region and their Integration to the Process of Development' (1994) designed and implemented by the Development Foundation of Turkey (TKV), under the guidance and supervision of Dr Ahmet Salt1k; 'Survey on the Problems of Employment and Resettlement in Areas which will be Affected by Dam Lakes in GAP Region' (1994) designed and applied by the Sociology Association, under the supervision of Dr Birsen Gökçe; and 'Population Movements in the GAP Region' designed and conducted by the Department of Sociology, Middle East Technical University (METU or ODTÜ, 1993), under the supervision of Dr Bahattin Akşit. In addition to these surveys, a fifth one was conducted on the 'Management, Operation and Maintenance of GAP Irrigation Systems' planned, designed and implemented by Halcrow, Dolsar and RWC jointly. The sociological dimension of this project was undertaken by the Department of Sociology, METU (Aksit et al., 1994).

Some of the major findings of these research studies indicate that a defining characteristic of the region is its still highly effective ashiret, i.e. 'tribal', structure and accompanying sociopolitical institutions. Many of the critical features and aspects of social organization and life seem to derive from this peculiar mode of organization, which has its roots in the Osmanlı history, as sketched earlier.

Besides being an imperial state with many and distinct religious and social groups with varying sociopolitical and economic activities and organizations, Osmanl state had developed certain policies on the basis of real and urgent concerns regarding that region in particular which is at the threshold of the deserts to the south, as the last citadel of arable lands of Asia Minor. Beginning 
in the 1690s, the Osmanl were concerned with protecting the intercontinental trade routes which passed through the region, as well as preventing the desert nomads from attacking and pillaging the arable, cultivated lands there. Therefore, they instituted large-scale settlement programmes all over the region including parts of present Iraq and Syria. This policy of (re)settlement of masses in the region continued with semi-success and semi-failure due to the Badawi fear of the population settled in those agricultural zones. What happened in the end (as a result of continued efforts to settle people, the 1878 Russian-Ottoman War, the First World War, etc.) is the firm establishment in the region of tribal organization once more.

In addition to the long-established (re)settlement policy of the Osmanli government-historically, the 1854 Land Act; the formation of Hamidiye Cavalries against the Russian advances in the 1870s from tribal groups, under the leadership of their traditional leaders, some of whom received military education and training in Istanbul; the 1924 Village Act; and finally the introduction to the countryside of a total of 40000 tractors in the $1940 \mathrm{~s}$ for agricultural purposes, with no prior study or inquiry-contributed a lot to the formation of this picture. The new Land Act legitimized the possession of huge areas of land by the sheikhs (tribal and/or religious leaders). The chiefs or commanders of the Hamidiye Cavalries, who were also tribal leaders, were granted rights to exact taxes, and to make use of grazing zones and highlands for their herds, etc. And the Village Act turned into village common properties the traditional pastures of nomadic and semi-nomadic tribes of the region, who were thus left with nothing besides their herds and tents. All these not only brought further friction and/or hostilities among various sectors of the population, but also reinforced the traditional mode of tribal organization in the region.

The tribal or ashiret type of social organization, together with the historical reasons sketched above, brought a specific sense of insecurity in south-east Anatolia. This translates into a need for manpower, for he who has the most manpower is considered the strongest and hence the most respectable. This, in turn, brings polygamy (Sencer, 1992-93; TKV, 1994; see also Gökalp, 1975), as the easiest, most efficient (plus traditionally acceptable and religiously permissible) way to have as many children, and as many allies through marriages, as possible. One consequence of this is a high birth rate, which in turn brings a high child mortality rate, because of insufficient health care (TKV, 1994), and traditional attitudes towards health problems (such as trusting in local tribal elders rather than medical doctors). This leads to rapid and endless division of land among sons in every generation, on the one hand, which in turn leads many people to have one piece of land which is good for nothing (see Sencer, 1992-93, p. 248). Many of these people either sell their land and go to the urban centres with no skill for work other than cultivation, or begin to work for the landlords with little money and in kind, in addition to cultivating their own plot. Some of these people work as seasonal workers in other regions such as the Çukurova basin (ODTÜ, 1993). On the other hand, it leads many others to practise such age-old traditions as brother's son/brother's daughter marriages for many generations to come.

These (traditional) efforts to maximize the number of members of a household, and the ensuing land fragmentation, lead to landlessness of many people (Sencer, 1992-93, p. 246). Furthermore, it brings severe competition among 
people, which leads to even higher bride prices and inability to get married for those who lack the necessary economic means and, eventually, to blood feuds.

Scattered residence in the most secure, inaccessible places (historically, for protection from the Badawis, for pastoral activities, and due to inter-ashiret conflict) is another result, which effectively disables efforts to provide healthcare, education, transportation, etc. It is neither possible nor economically viable to bring the necessary facilities to those communities whose sizes range from two to 10 households. At present, the number of these sub-village settlements (called mezra,kom, etc.) far exceeds the number of villages in the region.

The GAP Administration is currently making every effort to change this picture. A most recent example of the continued efforts of the GAP Administration is the establishment of multipurpose Community Centres (ÇATOM, in Turkish) both in urban areas and the countryside. These centres aim at raising the status of women in the region, by training and educating them to gain income-generating skills and providing them with necessary information on health issues and child care as well as education, since women among all are the least privileged section of society in the region. At present, female children are not even allowed to have a decent education as a result of socioeconomic and religious reasons, and are married at very young ages at 'prices' non-affordable by many families.

Other social projects to be implemented within the framework of GAP include the resettlement of those whose dwelling places or fields will be influenced by dam lakes (Sosyoloji, 1994); reorganization of the urban informal sector through education and training for regular jobs of mostly rural origin people who flood into the cities with few or no skills beyond cultivation; establishing busing systems for the children of the scattered communities; and settlement of nomadic people whose prospect for using the south-eastern soil for grazing is approaching zero. Through infrastructural investments and implementation of such social projects, around the year 2005, GAP is estimated to create employment opportunities for about 3500000 million people.

\section{Notes}

1. Throughout the text nomadic, ashiret (and, occasionally, tribe/tribal) are utilized interchangeably, and should be read as such unless otherwise cited. Other words used in the literature for nomad include yörük/yürük and Turkmen.

2. The studies that provide background information for this period are those on the classical age of the Osmanlı Empire (İnalcık, 1973; Shaw I, 1974).

3. This point is crucial in that taxes from the reaya, as a rule, were being extracted on the basis of the population of settlement units. The unit of taxation was the village or the estate. Therefore, tax-gatherers were demanding a certain amount of tax from each unit as before, regardless of the number of current residents. This method worked well under normal conditions. The amounts and kinds of tax were set by the lawbooks and the registers were updated at regular intervals in order to take account of such factors as population increase. Since both during and after the Great Escape the tax collectors insisted (under local administrations' orders) on securing the same amount as before from each unit, the remaining two-thirds were faced with de facto extra taxation. This problem was solved later, when the governors recalculated the amounts subject to extraction at the beginning of the 17th century (Akdağ, 1975).

4. Among the people who were sent to Syria as part of this project were those who also practised agriculture as complementary to pastoral nomadism. As usual, these groups refused to pay raiyyet taxes whenever they felt strong enough to claim askerî, i.e. military status (Orhonlu, 1987, p. $81 \mathrm{ff}$.), and thus not be subject to taxation. The government deemed this argument valid for those resettled in Raqqa, and gave all the privileges that the others had in these areas. 
5. A series of orders and decrees were issued in 1691, beginning on 11 January (10 Rebî-ülâhir 1102). One of these states that:

As their animals customarily are taken to summer-lands, let them not take them themselves but stay behind with their spouses and families at the specified locations, and send them by their shepherds, and let no one prevent their movement. (cited in Orhonlu, 1987, p. 51; translation by the present author).

The same decree continues as follows:

In the event that they do not obey and want to go to the highlands, the royal decree is issued for the people of Behısnı, Hisn-1 Mansûr and Göynük, and for Küpeli Hasan and Ya'kub Beg-oğlı Halil Beg ashirets to block the residence centres and not to allow them to the Elbistan and Malatya territories. (ibid., p. 51; translation by the present author)

6. For several examples of such cases of disturbances caused by nomads, see Uluçay, 1955, pp. 80ff, $105,132,142,167,183,196,215$, etc.

7. For example, in the 1840 s, the Tanzimat government used some nomadic ashirets to complete the destruction of a derebey (local notable, 'feudal') family, which ran the $M u$ ş Beylerbeyliği (Muş Governorship) until it was annulled by the new government. The lack of governmental backing did not matter much since the official duty was assigned to the members of the same family for some time. Only after this family had been defeated, with the support of nomads, could government establish new administrative organs. Thereafter, the town Varto became a kaymakamlık (district head office) and Muş became a mutasarrıflık, i.e. jurisdiction of the 'provincial' (sancak) governor (Firat, 1983, p. 120).

8. Quite understandably, western scholars speak very favourably of this privatization of land in the Osmanlı Empire. As for the social, economic and political effects or consequences of this process, however, I think one should be more careful in declaring it a great success and presenting it as the ultimate solution to the problems that the Empire had been experiencing for many decades.

9. The "government in 1865-66 sent a military expedition, Firka- Islahiye (hence the town's name), to the inner Taurus and Amanos mountains" both "to destroy the power of the derebey families" and to settle the nomads (Bates, 1973b, p. 34, note 9).

10. Just as in earlier centuries, the state granted lands to settling groups, in addition to giving private titles to chiefs and other notables which it had begun to issue more readily. The Reyhanli confederation was among those who settled on the Amik plain in Antakya by government decree "in such an attempt to control and to obtain taxes and military support" in 1859 (Aswad, 1971, p. 19). At the time, it "was composed of forty tribal sections that had banded together from various regions to resist increasing tax demands by the government and threats made against their caravans by mountain tribes" (ibid., p. 29). They were estimated to be nearly 30000 persons (ibid.; see also p. 21).

11. In spite of their utilization by many historians and alike as synonyms (e.g. the title of Orhonlu's study, 1987, on the settlement of nomads is Osmanlı Imparatorluğunda Aşiretlerin İskânı, that is, literally, Settlement of Ashirets in the Ottoman Empire), the words ashiret and nomad do not always appear exclusively as synonyms in Turkish literature. The historian Kodaman uses them interchangeably in his study, Sultan II. Abdülhamid Devri Doğu Anadolu Politikası (1987; see also Akdağ, 1975, pp. 52-53). In two places, he explicitly states, within the context of tax exemptions instituted by the state to encourage recruitment, that such exemptions did not appeal to the ashirets much since they were already exempt from them as nomads or semi-nomads, and had very little to do with the raiyyet taxes that crop cultivation brought (1987, p. 44; see also p. 49).

12. Similar to the case of the Evlâd-ı Fâtihân, mentioned earlier, these regiments were highly esteemed in the Palace. Their leaders were called 'sons' by the Sultan and received several honorary gifts on their arrival at the Palace in İstanbul (Firat, 1983, p. 125).

13. This antagonism had its roots in the early 16th-century conflict between Osmanlıs and Safevîs, where the parties respectively held fast to the orthodox sunnî and shi'î sects of Islam (see Erhan, 1992, Ch. 2 for a more detailed discussion of this historical conflict, which in many ways has shaped the history of especially the eastern regions of Anatolia; see also Firat, 1983, p. 89ff.)

14. Although the Hamidiye regiments were disbanded in 1918, those who opposed Sheikh Said in 1925 used the devastating effects of the Hamidiye experience as an explanation of their mistrust of the rebelling forces, whom they identified with "the Hamidiyes" and referred to as such (Firat, 1983, p. 158).

15. One of the largest confederations in the area was Milli, then ruled by Ibrahim Pasha. It had about one thousand tents at the end of the 18th century, and was forced to settle at the time 
(Göyünç, 1969, p.79 n.4). Following the foundation of the Hamidiye Regiments, the Milli confederation soon recovered its previous posture and gained a very respectable place among the Regiments (Firat, 1983, p. 124). Ibrahim Pasha was among those who felt threatened by the new government and rebelled. He was soon defeated and, as a result, had to retreat and move further into the Syrian deserts (ibid., p. 141).

16. Hakki states (1932, p. 23) in his book on the Tunceli province (then, Dersim) of the early 1930s that in addition to the 7000 people living in six settlements and about 11000 Pertek and Çemişkezek villagers, 47000 of the Tunceli population, which at that time totalled 65000 , lived under the ashiret regime. Although to a much lesser degree, recent studies made in the south-east indicate that the ashiret or 'tribe' is still a viable mode of organization in the region. For instance, Sencer found out in his sample (1992-93, p. 335) that an average of $47 \%$ of the people have varying degrees of relationship with the ashiret system, which rises to $57.2 \%$ in the countryside and falls to $37.3 \%$ in urban areas (see also, Sosyoloji, 1994, p. 57).

17. Actually, this has been the case in most of Turkey. As Boran (1945, pp. 67-68) notes for the villages of Manisa in western Anatolia, the quarters or districts of most of the towns and villages in Anatolia are still known by the name of the families or groups that initially settled there. Through the process of sedentarization, the political term mahalle (which still signifies the group of closest families of agnates or even of affinals) has turned into a term indicating district of permanent residence (see also Benedict, 1974).

18. Hakk1 notes (1932:10) that in the Tunceli area some local lords owned 10, 20/or even 189 villages in the early 1930s. For the extent of landlessness in the southeast, see ODTÜ (1993, p. 26); Sencer (1992-93, p. 188ff., 248, 335); and Sosyoloji (1994, p. 24).

\section{References}

Akdağ, M. (1975) Türk Halkının Dirlik ve Düzenlik Kavgası: Celali İsyanları (Ankara, Bilgi Yayınları).

Aksit, B. et al. (1994) GAP Sulama Sistemlerinin işletme, Bakim ve Yönetimi Projesi: Sosyo-Ekonomik Çalişmalar (Ankara, T.C. Başbakanlik Güneydoḡlu Anadolu Projesi Bölge Kalkinma idaresi Başkanliği).

APD (Araştırma ve Planlama Dairesi) (1971) Göçebe ve Gezginci Nüfusun Uzun Vadeli İskan Planlaması (T.C. Köy İşleri Bakanlığı, Toprak ve İşleri Genel Müdürlüğü).

Aswad, B. (1971) Property Control and Social Strategies in Settlers in a Middle Eastern Plain (Michigan, University of Michigan Press).

Aydin, Z. (1980) Aspects of rural development in southeastern Turkey: the household economy in Gisgis and Kalhana, unpublished dissertation, University of Durham, Dept. of Sociology and Social Policy.

Balaban, A. (1986) Güneydoğu Anadolu Projesi (GAP) Entegre Sistemi, Planlama ve Uygulama Sorunları, in: GAP: Güneydoğu Anadolu Projesi Tarımsal Kalkınma Simpozyumu,18-21 Kasım 1986 (Ankara, TÜBİTAK, Ankara Üniversitesi Ziraat Fakültesi, T.C. Ziraat Bankası, Ankara Üniversitesi Basımevi), pp. 1-17.

Bates, D.G. (1971a) Güney-Doğu Anadolu'da Göçebe Yörük Yerleşmeleri Üzerine Bir Çalışma (A Study on the Nomadic Yörük Settlements in South-East Anatolia), in: E. Tümertekin, F. Mansur \& Benedict (Eds) Türkiye: Goğrafî̀ ve Sosyal Araştırmalar (İstanbul, İÜ, EF, Coğrafya Enstitüsü), pp. 245-292.

Bates, D.G. (1971b) The role of the state in peasant-nomad mutualism, AnthropologicalQuarterly, 44, pp. 109-131.

Bates, D.G. (1973a) Shepherd becomes farmer: a study of sedentarization and social change in Southeastern Turkey, in: E. Tümertekin, F. Mansur, \& P. Benedict (Eds.) Turkey: Social and Geographic Perspectives (Leiden, E.J. Brill), pp. 92-133.

Bates, D.G. (1973b) Nomads and Farmers: A Study of the Yörük of Southeastern Turkey, Anthropological Papers No. 52 (Ann Arbor, University of Michigan, Museum of Anthropology).

Bayrak, M. (1984) Anadolu'da Eşkıyalık ve Eşkıyalık Türküleri (Ankara, Yorum).

Benedict, P. (1974) Ula: an Anatolian Town (Leiden, E.J. Brill).

Beşikçi, İ. (1969a) Doğuda Değişim ve Yapısal Sorunlar: Göçebe Alikan Aşireti (Ankara, Doğan Yayınları). Beşikçi, İ. (1969b) Doğu Anadolu'nun Düzeni, Sosyo-Ekonomikve Etnik Temeller (Ankara, E. Yayınları). Boran, B.S. (1945) Toplumsal Yapı A raştırmaları: 'İki Köy Çeşidinin Mukayeseli Tetkiki,' (Ankara, Ankara Üniversitesi, DTCF, Felsefe Enstitüsü, Sosyoloji Serisi: 3, TTK Basımevi).

Brow, J. (1990) Notes on community, hegemony, and the uses of the past, Anthropological Quarterly, 63(1), pp. 1-6. 
Çavdar, T. (1984) Talat Paşa: Bir Örgüt Ustasının Yaşam Öyküsü (Ankara, Dost Kitabevi Yayınları) (1. Bask1).

Çetintürk, S. (1943) Osmanlı İmparatorluğunda Yürük Sınıfı ve Hukuki Statüleri, A ̈̈, DTCF Dergisi, II(1), pp. 107-116.

Demirtaş, F. (1949) Bozulus Hakkında (On Bozulus), A ̈̈, DTCF Dergisi, VII(1), pp. 29-60.

de Planhol, X. (1959) Geography, politics and nomadism in Anatolia, International Social Science Journal, (UNESCO), XI(4), pp. 525-531.

Eberhard, W. (1967) Nomads and farmers in Southeastern Turkey: problems of settlement, in: Settlement and Social Change in Asia (Hong Kong, Hong Kong Univ. Press), pp. 279-296.

Erhan, S. (1992) Identity formation and political organization among Anatolian nomads: the Beritanı case, unpublished dissertation, University of Texas, Austin.

Erhan, S. (1993) The Beritanlı and national politics: settlement and new identities, Turkish Studies Association Bulletin, 17(2), pp. 57-67.

Faroqhi, S. (1982) Camels, wagons, and the Ottoman state in the sixteenth and seventeenth centuries, International Journal of Middle East Studies, 4(4), pp. 523-539.

Firat, M. Ş. (1983 [1948]) Doğu Illeri ve Varto Tarihi (The History of Eastern Provinces and Varto), (Ankara, Kardeş Matbaası).

Gökalp, Z. (1975 [1905) Kürt Aşiretleri Hakkında Sosyolojik Incelemeler (Sociological Inquiries on Kurdish Ashirets) (Ankara, Komal Yayınları).

Gökbilgin, M.T. (1957) Rumeli'de Yürükler, Tatarlar ve Evlâd-ı Fâtihân (Yürüks, Tatars and the Evlad-ı Fatihan in Rumelia) (İstanbul, İÜ, E.F. Yayınları), No. 748

Göyünç, N. (1969) XVI. Yüzyilda Mardin Sancaḡi (The Mardin Province in the XVIth Century) (İstanbul, r..ü., E. F. Yyl.), Sayi 1459.

Gülöksüz, G. (1985) The Beritan nomads over time and the problems of their settlement, unpublished PhD dissertation, Middle East Technical University City and Regional Planning, Ankara.

Hakk1, N. (1932) Derebeyive Dersim (no publication details known).

Halaçoğlu, Y. (1988) XVIII. Yüzyılda Osmanlı İmparatorlü̆u'nun İskân Siyaseti ve Aşiretlerin Yerleştirilmesi (Ankara, A tatürk Kültür, Dil ve Tarih Yüksek Kurumu, TTK Yayınları), VII. Dizi (92).

Hütteroth, W.D. (1973) The influence of social structure on land division and settlement in inner Anatolia, in: E. Tümertekin, F. Mansur \& P. Benedict (Eds), Turkey: Social and Geographic Perspectives (Leiden, E.J. Brill), pp. 19-48.

İnalcık, H. (1973) The Ottoman Empire: The Classical Age: 1300-1600,(trans. N. Kowitz \& C. Imber) (London, Weidenfeld \& Nicolson).

Kodaman, B. (1987) Sultan II. Abdulhamit Devri Doğu Anadolu Politikası (Ankara, Türk Kültürünü Araştırma Enstitüsü Yayınları), No. 67.

Kutlu, M. (1987) Şavaklı Türkmenlerde Göçer Hayvancılık (Nomadic Animal Breeding among the Şavaklı Türkmens) (Ankara, Sevinç Basımevi, Kültür ve Turizm Bakanlığı, Milli Folklör Araştırma Dairesi Yayınları), 84, Gelenek-Görenek ve İnançlar Dizisi.

Lewis, N.N. (1987) Nomads and Settlers in Syria and Jordan, 1800-1980 (London New York New Rochelle Melbourne Sydney, Cambridge University Press).

Orhonlu, C. (1987 [1963]) Osmanlı İmparatorluğunda Aşiretlerin İskânı (Settlement of Nomads in the Ottoman Empire) (İstanbul, Eren Yayıncılık ve Kitapçılık Ltd. Sti.)

ODTÜ Sosyoloji Bölümü GAP Araştırması Ekibi (1993) GAP Bölgesi Nüfus Hareketleri Araştırması (Ankara: T.C. Başbakanlık Güneydoğu Anadolu Projesi Bölge Kalkınma İdaresi Başkanlığı).

Sencer, M. (1974) Toprak Ağalið̆inin Kökeni (The Origin of Landlordship) (İstanbul, Tel Yyl.)

Sencer, M. (Proje Yöneticisi) (1992-93) GAP Bölgesinde Toplumsal Değişme Eğilimleri A raştırması (Bölüm I: GAP Bölgesinin Sosyo-ekonomik Profili) (Ankara, T.C. Başbakanlık Güneydoğu Anadolu Projesi Bölge Kalkınma Idaresi Başkanlığı).

Shaw, S.J. (1974) History of the Ottoman Empire and Modern Turkey, I: Empire of the Gazis-the Rise and the Decline of the Ottoman Empire, 1280-1808(Cambridge London New York Melbourne, Cambridge University Press).

Shaw, S.J., \& Shaw, E.K. (1978) History of the Ottoman Empire and Modern Turkey, II: Reform, Revolution and Republic-The Rise of Modern Turkey, 1808-1975 (Cambridge London New York Melbourne, Cambridge University Press).

Sosyoloji Derneği (1994) GAP Bölgesi Baraj Göl Aynasında Kalacak Yörelerde İstihdam ve Yeniden Yerleşim Sorunları Araştırması (Ankara, T.C. Başbakanlık Güneydoğu Anadolu Projesi Bölge Kalkınma İdaresi Başkanlığı).

Sümer, F. (1960) Anadolu'ya Yalnız Göçebe Türkler mi Geldi? (Did Only Nomadic Turks Come to Anatolia?/Was it Only the Nomadic Turks Who Came to Anatolia?), Belleten, XXIV(96), pp. 567594. 
Sümer, F. (1976a) Safevî Devletinin Kurulşu ve Gelişmesinde Anadolu Türkmenlerinin Rolü (Ankara). Sümer, F. (1980) Oğuzlar (Türkmenler): Tarihleri-Boy Teşkilatı Destanları [The Oguz (The Turkmens): Their History-Organization-Mythologies] (İstanbul, Ana Yayınları).

Türkiye Kalkınma Vakfı (TKV) (1994) GAP Bölgesinde Kadının Statüsü ve Kalkınma Sürecine Entegre Edilmesi Araştırması (Ankara, T.C. Başbakanlık Güneydoğu Anadolu Projesi Bölge Kalkınma İdaresi Başkanlığı).

Tütengil, C.O. (1969) Türkiye'de Köy Sorunu (İstanbul: Kitapçılık Ticaret Limitet Şirketi, Kitaş Bilim Dizisi, No:3)

Uluçay, M.Ç. (1955) 18. ve 19. Yüzyıllarda Saruhan'da Eşkiyalık ve Halk Hareketleri (Banditry and Popular Movements in Saruhan in the 18th and 19th Centuries) (İstanbul, Berksoy Basımevi).

Uzunçarşılı, I.H. (1969) Anadolu Beylikleri ve Ak Koyunlu-Kara Koyunlu Devletleri (Anatolian Principalities and the Ak Koyunlu and Kara Koyunlu States) (Ankara, Türk Tarih Kurumu Yayınları).

Yalgın (Yalkın/Yalman), A.R. (1977) Cenupta Türkmen Oymakları,2 vols (Ankara İstanbul, T.C. Kültür Bakanlığı Yayınları, Kültür Eserleri, No. 14, M.E.B. Basımevi). 